\title{
The formation of loess ground by the process of loessification: a history of the concept
}

\author{
Ian Smalley ${ }^{1 *}$, Igor Obreht ${ }^{2}$ \\ ${ }^{1}$ Centre for Loess Research \& Documentation, School of Geology, Geography \& the Environment, Leicester University, \\ Leicester LE1 7RH, United Kingdom \\ ${ }^{2}$ Organic Geochemistry Group, MARUM-Centre for Marine Environmental Sciences, Department of Geosciences, \\ University of Bremen, Leobener Straße 8, 28359 Bremen, Germany \\ * corresponding author, e-mail: ijs4@le.ac.uk
}

\begin{abstract}
Loessification is a process by which a body of non-loess ground is transformed into a body of loess ground. The history of loessification is one of controversy and confrontation, largely because of mutual misunderstandings between geologists and pedologists. Lev S. Berg is the 'only begetter' of the theory, first proposed in 1916, and propagated throughout his life. R.J. Russell proposed the same approach to the loess in the Lower Mississippi valley in his famous 1944 paper, which contributed enormously to the study of loess in North America. As understanding of the various processes involved in the formation of loess deposits has developed, a compromise position on loess formation has become possible. The major intrinsic features of loess deposits are the open structure and the collapsibility. It appears that the open structure is caused by aeolian depositional processes and the collapsibility is caused by loessification processes. The compromise was initiated by Marton Pécsi in 1990, He endeavoured to retain a loessification aspect in the study of loess deposits, as the subject appeared to be overwhelmed by the aeolian idea system promoted by geologists; it has been mostly a Central European endeavour. The history of the concept of loessification largely involves (1) its development in Russia, (2) its dissemination and discussion - and attempts at refutation and modification - in the wider world.
\end{abstract}

Key words: loess origin, soil processes, L.S. Berg, R.J. Russell, M. Pécsi

"Now I am ready to tell how bodies are changed into different bodies." Ovid/Ted Hughes: Metamorphoses

"Sweet and pleasing to me is... the loess dust of Turkestan." L.S. Berg

\section{Introduction}

This paper presents a history of the concept of 'loessification', i.e., the process whereby nonloess ground is transformed into loess ground; or perhaps, slightly loessic ground becomes more loessic. Sprafke \& Obreht (2016) discussed the philosophical, scientific and semantic aspects of loessification and added welcome complexity to the study of the two approaches (sedimentological or pedological) to the visualization and explanation of the processes that lead to formation of loess deposits. The present paper is another contribution to the discussion of the idea of loessification; it 
adds little to the argument, the main aim being to clarify the early history and to rework some of the early ideas. The key items of literature, in addition to Sprafke \& Obreht (2016) are Berg (1916, 1927a), Russell (1944) and Pécsi (1990). Sprafke \& Obreht (2016) contrived to publish their commentary on the $100^{\text {th }}$ anniversary of the publication of the theory of loessification and on the $140^{\text {th }}$ anniversary of the birth of Lev S. Berg.

The concept of loessification is present in current loess research. For example, Li et al. (2017, p. 271) used the term in a very relaxed manner, "The present day structure of loess results from the loessification process (Smalley et al., 2006b) and it determines the mechanical behaviour and engineering properties". "After the accumulation of windblown dust, the loess experiences a long period of structural evolution, called loessification (Smalley et al., 2011)". Li et al. (2017) suggested that loessification was central to the development of structure and the nature of the properties of loess.

\section{Development of Berg's theory in Russia}

Berg is central; this is Berg's theory - it may be that it grew out of Berg's worldview of geography, augmented by a close association with the world of V. Dokuchaev and exposure to the new ideas of soil science. He was certainly well placed to be influenced by Dokuchaev and the ideas of soil science. Soil science was important in St Petersburg/Leningrad at the beginning of the twentieth century.

Lev Semenovich Berg (Fig. 1) was born in Bendery (Bessarabia), in 1876, and died in Leningrad in 1950. He was the ultimate scholar; he published 217 papers and monographs on ichthyology, 30 on general zoology and biology, 20 on palaeontology, 32 on zoogeography, 320 papers and monographs on geography, geology and ethnography, as well as 290 biographies, obituaries and popular articles. He published his theory of loess formation in 1916, and promoted it throughout his life (see Smalley \& Rogers, 1997; Smalley et al., 2006a, 2010). Ironically enough, despite many exposures in Russia, the 'soil' or 'in-si$t u^{\prime}$ or 'pedological' theory, involving loessification, is now probably best known via the translation of Berg's paper (1927b) into English by A. Gourevitch (Berg, 1964). We treat this as the definitive statement of loessification, which Smalley \& Marković (2013) called 'grand Loessification gL (see Chapter 7)'.

The Berg theory is relatively easy to summarise, as follows, "Loess and loess-like rocks have one and

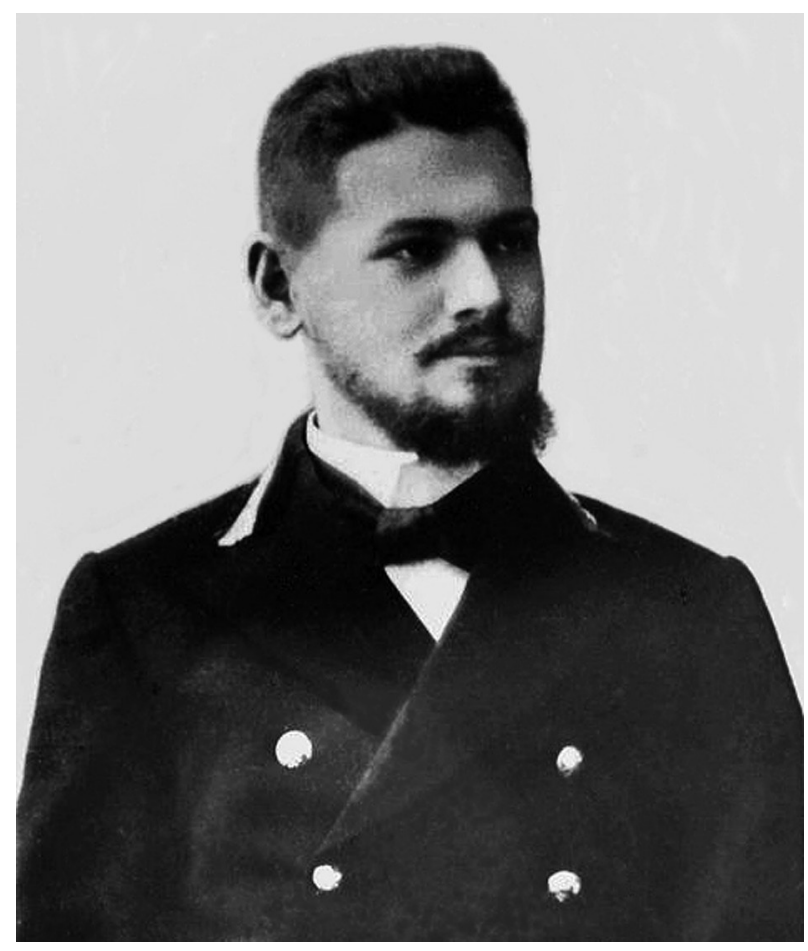

Fig. 1. Lev S. Berg, about ten years before publication of his loess theory and at the time of the Aral Sea investigations ( 1905).

the same origin: they form out of fine-earth molecules, necessarily carbonatic, and they form in-situ, by weathering and soil formation in a dry climate. Some rocks of uniform texture are particularly apt to give rise to loess and loess-like materials, e.g. certain alluvial and fluvioglacial deposits (and also diluvium). This accounts for the frequent connections between loess regions and glaciated regions." (Berg, 1964). These phrases appear three times in Berg (1964); on pages 1, 18 and 142. Berg (1964) is the translation of Berg (1947) which was the second edition of Berg (1922), which, in effect, was a reissue of Berg (1916). Very little changed in the loess story as told by Berg. His insistence was that loess formed in situ; the formation of loess was much like the horizonation process occurring in the classic development of soil - the great insight of Dokuchaev, which resounded particularly loudly in St Petersburg/Leningrad, city of Dokuchaev, Berg and Gerasimov.

\section{Berg's theory in wider world}

When Obruchev published his classic study, which initiated the pursuit of 'desert' loess, it came out in Russian in a very obscure journal published in Tomsk (Obruchev, 1911). It appeared destined for 
obscurity but Merzbacher (1913) published a long and detailed appreciation of it in Petermanns Geographische Mitteilungen (an important geographical journal at the time) and it became known throughout Europe. Berg had a similar experience; his long paper from 1916 (66 pages) was published in the Communications of the Russian Geographical Foundation, and his ideas were given wide exposure in Europe by Anger \& Wittschell (1929), also writing for Petermanns Geographische Mitteilungen.

Berg (1932) published a lengthy paper in English, which can deliver a few useful quotations and insights, "The second objection, which has frequently been raised, is the following. It is absolutely incomprehensible, why the wind should drive sediment of only that texture which is characteristic of loess. The wind, according to its velocity, can carry either coarser or finer particles, but why it should give a preference to particles of 0.01 to $0.05 \mathrm{~mm}$ in diameter, has never yet been explained by any follower of the aeolian theory." (Berg, 1932, p. 135).

Berg's logic appears to desert him here; there are two good reasons why the wind would pick up particles in the $10-50 \mu \mathrm{m}$ range. The particle being picked up is subject to two sets of forces: a weight force tending to resist being raised by the wind, and an interparticle cohesive force tending to maintain the integrity of the superficial deposit (Smalley, 1970). A large particle cannot be lifted, a very small particle has a high cohesion; the compromise size is at about $80 \mu \mathrm{m}$; coarse silt tends to get lifted. And if some earlier control has been operating, say controlling the particle size in the comminution process, then the wind will be lifting from a deposit which has a high proportion of coarse silt particles (see Smalley \& Marković, 2017).

The response to Berg (1964) suggests that there was some acceptance of loessification in the wider world during the 1960s. Thomasson (1965) reviewed the book for the Geographical Journal, offering a geographical view of loess. He was receptive to the $\mathrm{gL}$ view of loess, "Berg voices a number of shrewd criticisms of the popular aeolian theory. It is difficult to find a contemporary wind deposit which closely resembles loess in texture. The theory that loess is deflated from dry or unvegetated surfaces, and 'trapped' in moister or warmer areas by a vegetation cover may be difficult to sustain in continental regions where vegetation implies a soil cover with appreciable organic matter (Thomasson, 1965; see Smalley, 1971 p. 81; 1975, p. 357)". Thomasson was writing as a soil scientist and his review was commented on by Ollier (1969) and Smalley (1971). Ollier, seeing the geo-world in the context of weathering, was sympathetic; Smalley, from the position of clastic sedimentology, was less so. This did not prevent a sincere appreciation of Berg and his works (see Smalley et al., 2006a, 2010).

\section{The Ganssen experiments}

R. Ganssen made a modest contribution to the study of loess, but because his experiments were discussed by Russell (1944) and by Berg (1964), an echo of this contribution remains. Berg, to some extent, relied on Ganssen, "Ganssen (1922a, p. 41) has made the following remarkable experiment. A kaolin sample was exposed to the action of alkaline silicates. Towards the end of the experiment it appeared that nearly half of the kaolin, which cannot be decomposed by muriatic acid $[\mathrm{HCl}]$ was transformed into zeolite silicates decomposable by muriatic acid. At the same time its texture had undergone the remarkable alterations (Table 1). As may be seen, after the action of alkalies, the diameter of particles increased, and the texture approached that of loess. A similar process must have occurred in the parent rocks of loess also under the action of absorbed calcium and magnesium as also of carbonates of the same materials (Berg, 1964, p. 28)".

Table 1. The result of Ganssen (1922a) experiment.

\begin{tabular}{lcc} 
Particles of diameter & $\begin{array}{c}\text { Before } \\
\text { experiment }\end{array}$ & $\begin{array}{c}\text { After } \\
\text { experiment }\end{array}$ \\
\hline Finer than $10 \mu \mathrm{m}$ & $93.5 \%$ & $45.3 \%$ \\
$10-50 \mu \mathrm{m}$ & $3.3 \%$ & $43.2 \%$ \\
Coarser than $50 \mu \mathrm{m}$ & $3.3 \%$ & $11.6 \%$ \\
\hline
\end{tabular}

Russell took a different view, "Berg's evidence rested heavily on an experiment by Ganssen (1922a, p. 41) who subjected a sample of kaolin to the action of alkaline silicates. Loess-like texture was produced in kaolin. Ganssen gives few details concerning his methods. The end product was certainly not loess. The experiment was conducted as an attempt to explain how wind-transported dust might be changed to resemble loess. Ganssen apparently failed to realise that his experiment might be used to discredit the aeolian hypothesis, and Berg applied his results to that end" (Russell, 1944, p. 28).

Pyaskovskii (1946) was involved in the discussion of Ganssen's work, and raised some objections to Ganssen's approach, "An interesting attempt to solve the problem of loess formation was made by R. Ganssen. In his opinion (Ganssen, 1922a, b) the loess 'habitus' is acquired by strata as a result of weathering of hydrates". 


\section{Loess as a deep soil}

Pyaskovskii's 1946 paper on loess as a deep soil formation was published just in time for Berg to notice it, and to comment on it in the 1947 edition of Climate $\mathcal{E}$ Life. Pyaskovskii (1946) came out just as Berg (1947) was sent to the press. Berg just had time to add a short note about the paper (see Berg, 1964, p. 144) which may be the last significant thing he wrote about loess. He essentially agreed with Pyaskovskii's approach, "When the present paper was already at the printers, I received an interesting article by B.V. Pyaskovskii, Loess as a Deep-Soil Formation. The author reaches the conclusion that 'loess is a formation arising below the soil proper, on dry and semi-dry steppes, or - in other words - it is a definite and deep horizon of the soil, in the wider sense, and may be called horizon ' $\mathrm{L}$ '. I hold no objections to this view. But one should not forget that loess, which mostly occurs in regions having now a temperate climate, is really a relict - a result of weathering and soil formation in an environment where the climate was drier than that of the present" (Berg, 1964).

The Pyaskovskii paper deserves a close reading and careful analysis. In many ways it is very supportive of Berg's position, but it could be read as a fairly severe criticism. It opens with a paean of praise for Berg, "There can be no doubt that the most important factor in the development of our knowledge concerning loess was the fruitful idea of L.S. Berg as presented in a series of articles and collected under the title of The Pedological Theory of Loess Formation (Berg, 1916, 1922, 1926, 1927a, 1929, 1932b)."

\section{The Mississippi valley}

Russell (1944) offered an explanation of the Lower Mississippi valley loess which was very similar to that proposed by Berg for the Chernigov loess. Russell's paper had a great effect on loess studies in North America in provoking a considerable response; it probably was largely responsible for the publication in 1945 of the Loess Special Issue of the American Journal of Science (Elias, 1945). This special issue, in which several important papers were published, had considerable resonance; three of these were included in the Benchmark Collection of loess papers (Smalley, 1975).

Russell did not describe in any detail his proposed mechanism of loess deposit formation; he certainly relied on a process which he called loessification (a term which he surprisingly ascribed to Albrecht Penck), "The process of loessification starts in parent material that originally was deposited as alluvium on flood plains during the Pleistocene. It affects the finer parts of such deposits, especially those that have accumulated in backswamps and are present only in minor amounts along Pleistocene meander belts. It is restricted to parts of terrace formations that now stand considerably above flood plains. The deposits must consist mainly of silt and clay. They are somewhat calcareous and contain carbonaceous matter derived from plant remains. The initial stage of the process is weathering and differentiation of soil profiles" (Russell, 1944, p. 24).

\section{Not just the accumulation of dust}

Pécsi (1990) and Pécsi \& Richter (1996) represented the mature thinking of Marton Pécsi (Fig. 2) on the nature of loessification. His is perhaps the most complex contributions in the discussion of the topic of loessification. Berg and Russell set out their visions for loess formation; Russell in one brief moment and Berg throughout his life, but Pécsi, coming later, was faced with problems of reconciliation. As president of the INQUA Loess Commission he was aware of the fact that loess was regarded as the product of aeolian deposition, and that for many people that was enough (e.g., Pye, 1995). Stratigraphers and chronologists were dealing with deposits which were hundreds of metres thick and were best explained via a continuous but variable supply of aeolian dust. But Pécsi was a true loess enthusiast; he believed, like Berg and Obruchev, that loess was a uniquely special material, not just a random fall of dust. The process of loessification emphasizes the

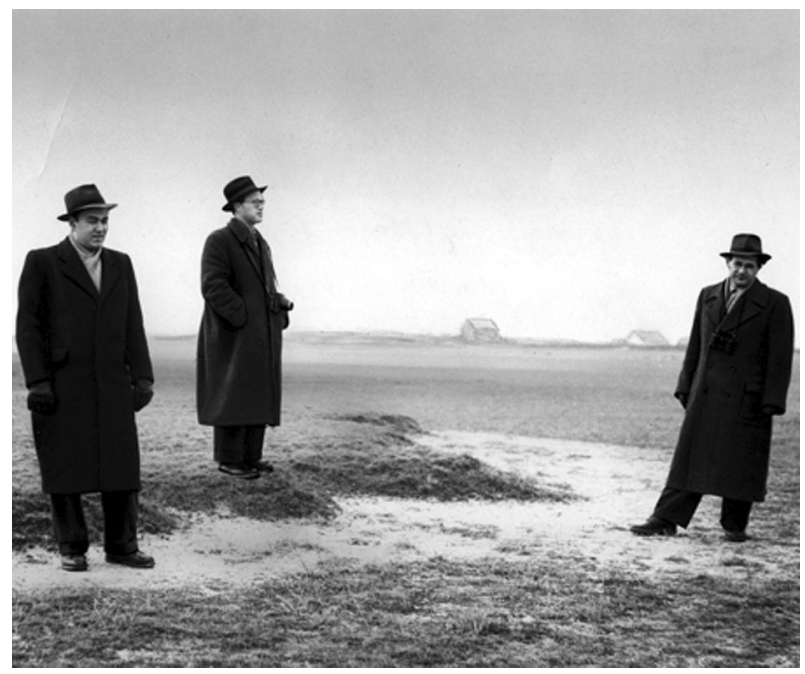

Fig. 2. Marton Pécsi (centre) with two of his colleagues of the Hungarian Academy of Sciences (Budapest): Sandor Marosi (left) and Lazlo Goczan (right). 
specialness - it separates loess (the special material) from non-loess, all other types of material. The loessic essence is delivered by loessification.

From these discussions by Pécsi, the simple idea of 'grand' loessification (gL) and 'petit' loessification (pL) developed (see Smalley et al., 2011; Smalley \& Marković, 2013). The pretentious terminology points to a simple idea, a way of demarcating, in discussion, the grand overall original idea by Berg that loess formed by loessification (gL) and that is that, and the developed idea that it might be necessary to invoke some post-aeolian depositional processes to explain some of the observed properties of loess ground ( $\mathrm{pL}$ ). Engineers in particular needed an explanation for hydroconsolidation and subsidence, which was not found in a simple aeolian model. It turned out that a post-depositional process was required to produce collapsibility in loess deposits (the so-called Milodowski process; see Smalley \& Marković, 2013). So gL does not work it cannot explain the provision of silt particles or the great thickness of the deposits, but pL does work and explain the collapsibility of loess.

\section{A view from Romania}

Geologists in North America favoured a geological approach to loess and were happy that it was an airfall sediment; after deposition all done and dusted (hoho). In Russia a pedological approach was favoured. There is a geography of loess and there is a geography of loess opinion. A view from Romania is interesting and useful; between two worlds - looking east and looking west; very much aware of the importance of rivers in the story of loess formation, and with a history of loess scholarship. Marosi (1970) at Cluj University made a well-regarded study of many aspects of loess investigation. Florea (2010, p. 160) conducted a study of loess formation with the idea of loessification to the fore, "Loess genesis from alluvial sediments was described by I. Simonescu, I. Atanasiu and N. Bucur and N. Brbu - the last ones attributing it to a fluvial origin combined with the loessification process for the loess of the Moldavian terraces".

"Loess genesis is one of the most discussed and controversial problems in the geological, geographical and pedological literature. In their study of loess and loess-like deposits, Marosi (1970) and then Gherghina et al. (2006) brought together many theories and hypotheses on the origin of these formations, grouping them by five categories" (Florea, 2010 , p. 159), in an attempt to demonstrate that the understanding of loessification was not only related to the primary (aeolian) loess, but also to loess-like deposits that are only partly related to aeolian deposition or not at all.

\section{Discussion}

Many authors have discussed the general idea of loessification (e.g., Ložek, 1966, 1968; Smalley, 1971; Pécsi, 1990; Cilek, 2001; Makeev, 2009). Perhaps the most thorough and thoughtful contribution is that by Sprafke \& Obreht (2016). They, in particular, tackle the idea of loessification as diagenesis, or as pedogenesis. Currently it is widely accepted that loess is an aeolian sediment that has experienced loessification. Both processes are necessary for loess formation or, in other words, loess is an accumulation of silt, but not any accumulation of silt is loess.

Makeev (2009) commented that Gerasimov (1962, 1969) had pointed out that pedogenesis in the cold arid environment existed during the time of accumulation of aeolian dust produced no soil profiles with clear horizonation. It resulted mainly in the formation of soil fabric and redistribution of carbonates. From the other side, diagenetic processes mainly through carbonate cementation seem to be very important, especially when it comes to the collapsibility of loess ground.

Pécsi \& Richter (1996, p. 130) touched on the topic of Urloess. This is to be a basic loess, a default loess or an undeveloped loess. This could well be the sort of loess found in New Zealand. The New Zealand loess does present problems in a discussion on loessification, in that it seems that no loessification has occurred. New Zealand loess is deposited by the wind but subsequent actions may not be described as loessification. Pécsi \& Richter (1996, p. 128) remarked that fragipans form in the New Zealand loess, but there is no sign of the carbonate movement as required in European loessification and the clay content is too great for collapsibility to develop. Thus, New Zealand loess is likely Urloess; this is loess defined by geology. The German prefix Ur- means early or ancient.

It seems that there is a connection between loessification and silt where there is some carbonate present in the system. Loessification does not occur without silt and carbonates, but dust does not turn into loess without loessification. Therefore, sandand clay-dominated deposits do not experience loessification even if environmental conditions for loess formation occur (which may be the case for Urloess, i.e., suitable conditions for loess formation, but lack of enough silt and carbonates and consequently no loessification and no collapsibility. 


\section{Commentary}

D'Arcy Wentworth Thompson wrote about Berg, "Books like Dr. Berg's are a help and a stimulus to such long and necessary discussion. Dr. Berg does not beat about the bush; he is intensely controversial, but he is modest withal; we may agree with him or not, just as we please; he says what he thinks in plain candid words, and he raises an issue on every page" (see Berg, 1969, p. xiv).

This is Thompson talking about 'Nomogenesis' rather than commenting on the loess work, but these general comments on Berg's approach probably apply to his loess deliberations as well as to his biological work.

As one of the most talented biologists of his time, Berg was a target of Trofim Lysenko and his followers. In January 1939, after discrediting Berg and the outstanding geneticist Nicolai Koltsov in the press, Lysenko and his accomplice Nicolai Tsitsin were elected in their stead as members of the Soviet Academy of Sciences. Berg was never formally recognised by the Soviet Academy for his accomplishments in biology, and only later (1946) was he elected a member of the Geographical Branch of the Soviet Academy of Sciences.

Possibly we should discuss the role played by I.P. Gerasimov in the debates about loessification and the controversies on the processes of loess formation. Gerasimov added little to the science of loessification but he was probably central to the 'politics' of loessification. It has been argued that the in-situ theory of loess formation became the 'official' theory of loess formation in the Soviet Union (see Blackburn, 1980; Smalley, 1980). A polarization developed whereby a Soviet in-situ view was opposed by a 'Western' aeolian view of loess formation. Gerasimov was a supporter of the Berg theory of loess formation and he was, for more than thirty years, the director of the Geographical Institute of the Soviet Academy of Sciences, and thus the official voice of Soviet geography. He was also one of the very few Soviet scientists allowed to travel abroad and thus his views on loess were the only ones heard outside the Soviet Union. At the time Soviet scientists were not encouraged to read Western literature and Russian literature was difficult of access. When the American Journal of Science was attempting a special loess issue in 1945 it proved very difficult to extract a short article by Obruchev (1945) from the Soviet system.

Gerasimov rose to some prominence before the war and delivered geographical addresses at the party conferences in 1938 and 1939. He was noted, with approbation, by Stalin, and this virtually as- sured a successful career in a powerful position. He became director of the Geographical Academy in 1951 and this sealed the in-situ theory into Soviet geography for many years.

Gerasimov, like Berg, had a background in Leningrad, the place where soil science was invented. He was a soil scientist, the most influential geographer by far in the Soviet Union, a firm adherent to the fundamentalist (gL) ideas of loessification and loess formation, essentially the only geographical voice from the Soviet Union heard outside the Soviet Union. When he went to New Zealand for the $9^{\text {th }}$ INQUA Congress in 1973 he looked at the South Island loess deposits and declared that they were not loess. Within his own definition system he was right; loessification, not even $\mathrm{pL}$ loessification, had not occurred in New Zealand.

\section{Afterword}

We come back to Berg; he is suitably historical. Many aspects of Berg could be noted, perhaps emphasized. There are ironies and paradoxes; he suffered at the hands of the Soviet system, which killed his friend Nikolai Vavilov, and because his path crossed that of T.D. Lysenko he was denied his rightful election to the Academy as a biologist. And yet, because of Gerasimov, the all powerful and long-established director of the Geography Academy his theory of loess formation ( $g L$ ) became in effect the official Soviet theory of loess formation. This idea of an official theory may be rather overstated and subjective (see Blackburn, 1980; Smalley, 1980) but it makes a passable generalisation. Aeolian (= Western) vs. Loessification (= Soviet). This prolonged the discussion and made the lives of review writers more interesting.

\section{References}

Anger, H. \& Wittschell, L., 1929. Die Loesstheorie von L.S. Berg. Petermanns Geographische Mitteilungen 75, 11-13.

Berg, L.S., 1916. The origin of loess. Izvestiya Russkogo Geografischeskogo Obshchestva [Communications of the Russian Geographical Foundation] 52, 579-646 (in Russian).

Berg, L.S., 1922. Climate and Life. Geografgiz, Moscow, 325 pp. (in Russian).

Berg, L.S., 1926. The soil theory of the origin of loess. Izvestiya Geograficheskogo Instituta 6, 73-92 (in Russian).

Berg, L.S., 1927a. The problem of loess I. Priroda 6, 411429 (in Russian). 
Berg, L.S., 1927b. Loess as a product of weathering and soil formation. Pedology 2, 21-37 (in Russian).

Berg, L.S., 1929. The problem of loess II. Pririoda 4, 317346 (in Russian).

Berg, L.S., 1932a. The origin of loess. Gerlands Beitrage zur Geophysik 35, 130-150 (reproduced in part in Smalley, 1975, pp. 61-75).

Berg, L.S., 1932b. Loess as a product of weathering and soil-formation. Proceedings $2^{\text {nd }}$ International Conference on Quaternary Period 1, 68-73 (in Russian).

Berg, L.S., 1947. Climate and Life. $2^{\text {nd }}$ edition. Geografgiz Moscow, 344 pp. (in Russian).

Berg, L.S., 1964. Loess as a product of weathering and soil formation. Israel Program of Scientific Translations, Jerusalem.

Berg, L.S., 1969. Nomogenesis. Massachusetts Institute of Technology Press, 666 pp.

Blackburn, G., 1980. The loess controversy. New Zealand Soil News 28, 106-107.

Cilek, V., 2001. The loess deposits of the Bohemian Massif: silt provenance, palaeometeorology and loessification processes. Quaternary International 76/77, 123-128.

Elias, M.K. (Ed.), 1945. Symposium on Loess. American Journal of Science 243, 225-303.

Florea, N., 2010. Loess was formed, but not sedimented. Romanian Journal of Geography 54, 159-169.

Ganssen, R., 1922a. Die klimatischen Bodenbildung der Tonerdesilikatgesteine. Mitteilungen der Abteiling fur Gesteins-, Erz-, Kohle- und Saltz-Untersuchungen. Preussische Geologische Landesanstalt 4, 1-34.

Ganssen, R., 1922b. Die Entstehung und Herkunft des Loesses. Mitteilungen der Abteilung fur Gesteins-, Erz-, Kohle- und Saltz-Untersuchungen. Preussische Geologische Landesanstalt 4, 35-46.

Gerasimov, I.P., 1962. Loess formation and soil formation. Pochvovedenie 2, 3-7 (in Russian).

Gerasimov, I.P., 1969. Loess, periglacial and palaeolithic of middle Europe and their interrelation. Pochvovedenie 6, 5-14 (in Russian).

Gherghina, A., Grecu, F. \& Cotet, V., 2006. The loess from Romania in the Romanian specialist's vision. Symposium Proceedings Edition Universitati Al.I. Cuza Iasi 5, 103-116.

Li, Y., He, S., Deng, X. \& Xu, Y., 2017. Characterisation of macropore structure of Malan loess in China based on 3D pipe models constructed by using computed tomography technology. Journal of Asian Earth Sciences in press.

Ložek, V., 1966. Das Problem der Loessbildung und die Loessmollusken. Eiszeitalter und Gegenwart 16, 61-75.

Ložek, V., 1968. The loess environment in Central Europe. [In:] Schultz, C.B. \& Frye, J.C.: Loess and related eolian deposits of the World. Proccedings of the $7^{\text {th }}$ INQUA Congress, Boulder \& Denver, Colorado, 1965. University of Nebraska Press, 67-80.

Makeev, A.O., 2009. Pedogenic alteration of aeolian sediments in the upper loess mantles of the Russian plain. Quaternary International 209, 79-94.

Marosi, P., 1970. A review of the evolution of theories on the origin of loess. Cluj University Studies, Geology $\mathcal{E}$
Mineralogy 15, 61-73. (in Romanian; English translation in Smalley, 1975, pp. 402-414).

Merzbacher, G., 1913. Die Frage der Entstehung des Loesses. Petermanns Geographisches Mitteilungen 59, 16-18, 69-74, 126-130.

Obruchev, V.A., 1911. The question of the origin of loess in defense of the aeolian hypothesis. Izvestiya Tomskogo Tekhnologicheskogo Instituta 33, 38 pp. (in Russian).

Obruchev, V.A. 1945. Loess types and their origin. American Journal of Science 243, 256-262 (reprinted in Smalley 1975 pp. 118-123).

Ollier, C., 1969. Weathering. Oliver \& Boyd, Edinburgh, $304 \mathrm{pp}$.

Pécsi, M., 1990. Loess is not just the accumulation of dust. Quaternary International 7/8, 1-21.

Pécsi, M. \& Richter, G., 1996. Loess: Herkunft - Gliederung - Landschaften. Zeitschrift fur Geomorphologie Supplementband NF 98, 391 pp.

Pyaskovskii, B.V., 1946. Loess as a deep soil formation. Pochvovedenie 11, 686-696. (in Russian; English translation as Loess Letter Supplement 3, July 1989; available online in Loess Letter 72: www.loessletter.msu. edu).

Pye, K., 1995. The nature, origin and accumulation of loess. Quaternary Science Reviews 14, 653-667.

Russell, R.J., 1944. Lower Mississippi Valley loess. Geological Society of America Bulletin 55, 1-40.

Smalley, I.J., 1970. Cohesion of soil particles and the intrinsic resistance of simple soil systems to wind erosion. European Journal of Soil Science 21, 154-161.

Smalley, I.J., 1971. 'In-situ' theories of loess formation and the significance of the calcium carbonate content of loess. Earth Science Reviews 7, 67-85.

Smalley, I.J. (Ed.), 1975. Loess: Lithology and Genesis. Benchmark Papers in Geology 26, Dowden, Hutchinson \& Ross, 430 pp.

Smalley, I.J., 1980. The loess controversy and Soviet science. New Zealand Soil News 28, 27-28.

Smalley, I.J. \& Marković, S.B., 2013. Loessification and hydroconsolidation; there is a connection. Catena 117, 94-99.

Smalley, I.J. \& Marković, S.B., 2017. Controls on the nature of loess particles and the formation of loess deposits. Quaternary International in press.

Smalley, I.J. \& Rogers, C.D.F., 1997. L.S. Berg and the soil theory of loess formation. [In:] History of Soil Science: International Perspectives. D.H., Yaalon \& S., Berkowicz (Eds): Advances in GeoEcology 29, Catena Verlag, Reiskirchen, 377-391.

Smalley, I.J., Jary, Z. \& O'Hara-Dhand, K., 2006a. Loessification: On the $130^{\text {th }}$ anniversary of the birth of L.S. Berg. New Zealand Soil News 54, 71-74.

Smalley, I.J., Marković, S.B. \& Svircev, Z., 2011. Loess is [almost totally formed by] the accumulation of dust. Quaternary International 240, 4-11.

Smalley, I.J., Jefferson, I.F., O'Hara-Dhand, K. \& Evans, R.D., 2006b. An approach to the problem of loess deposit formation: some comments on the 'in-situ' or 'soil-eluvial' hypothesis. Quaternary International 152/153, 120-128. 
Smalley, I.J., Marković, S.B., O'Hara-Dhand, K. \& Wynn, P., 2010. A man from Bendery; L.S. Berg as geographer and loess scholar. Geologos 16, 109-117.

Sprafke, T. \& Obreht, I., 2016. Loess: rock, sediment or soil - what is missing in its definition? Quaternary International 399, 188-197.
Thomasson, A.J., 1965. Review of books by Berg and Bespalov. Geographical Journal 131, 414-415.

Manuscript submitted 20 February 2018 Revision accepted 15 April 2018 